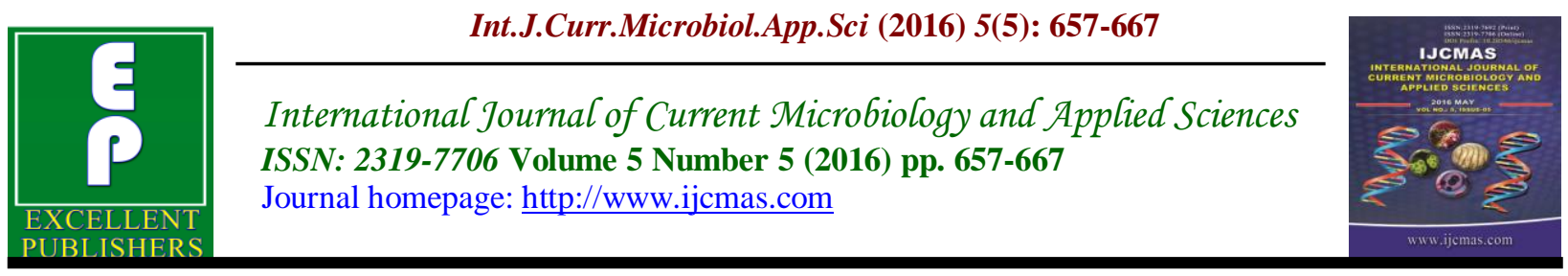

Original Research Article

http://dx.doi.org/10.20546/ijcmas.2016.505.066

\title{
Penicillium citrinum AVGE1 an Endophyte of Acorus calamus its Role in Bio Control and PGP in Chilli Seedlings
}

\author{
P. Ganga Mani and Amrutha V. Audipudi* \\ Department of Microbiology, Acharya Nagarjuna University, Nagarjuna Nagar, A.P, India \\ *Corresponding author
}

\begin{tabular}{|c|c|}
\hline & A B S T R A C T \\
\hline $\begin{array}{l}\text { Key w ord s } \\
\text { P. citrinum, } \\
\text { Colletotrichum sp, } \\
\text { 18s rRNAS, } \\
\text { plant growth } \\
\text { promotion, } \\
\text { chilli. }\end{array}$ & $\begin{array}{l}\text { An endophytic fungus isolated from rhizome of Acorus calamus Linn, was } \\
\text { identified as Penicillium citrinum (AVGE1), on the basis of morphological } \\
\text { characteristics and 18s rRNA partial gene analysis. This endophytic fungus was } \\
\text { evaluated for biocontrol of Collitotrichum acutatum and C. gloeosporioides, } \\
\text { pathosystems of chilli along with plant growth promotion in chilli at seedling } \\
\text { stage. P.citrinum (AVGE1) showed strong antagonistic activity against two } \\
\text { Colletotrichum sp. The activity of extracellular hydrolytic enzymes amylase, lipase } \\
\text { and protease was also high in this culture fluid. This isolate exhibited plant growth } \\
\text { promoting characters such as production of IAA, Ammonia and Phosphate }\end{array}$ \\
\hline Article Info & solubilisation. The levels of Phosphate solubilisation, IAA and Ammonia in \\
\hline $\begin{array}{l}\text { Accepted: } \\
18 \text { April } 2016 \\
\text { Available Online: } \\
10 \text { May } 2016\end{array}$ & $\begin{array}{l}\text { culture broth of P. citrinum (AVGE1) was incorporated into plastic pots containing } \\
\text { chilli seeds var. LCA } 334 \text { and growth data was recorded periodically at an interval } \\
\text { of } 2 \text { weeks. P.citrinum (AVGE1) significantly increased number of leaves, root and } \\
\text { shoot length, and leaf surface area in chilli plant compared to control. This study } \\
\text { revealed, endophytic fungi P.citrinum (AVGE1) enhancing growth in chilli } \\
\text { seedlings. }\end{array}$ \\
\hline
\end{tabular}

\section{Introduction}

Diseases caused by fungi, bacteria and viruses are the major constraints to chilli production in chilli growing countries. Anthracnose is one of the severe fungal diseases caused by Colletotrichum sp. in chilli and cause severe damage to the crop by reducing marketable yield from $10 \%$ to $80 \%$ in developing countries. Anthracnose is mainly a problem on mature fruits, causing severe losses due to both pre and postharvest fruit decay (Hadden, et al., 1989; Bosland, et al., 2003). The control of chilli anthracnose fruit rot has, for many years, relied on chemicals and resulted in many undesirable problems. There is a need to incorporate alternative control components that are effective in field. Biological control of fruit rot and dieback of chilli with plant products tested in many laboratories and field trials showed that the crude extract from rhizome, leaves and creeping branches of Sweetflag (Acorus calamus L.), palmorosa (Cymbopogon martinii) oil, Ocimum sanctum leaf extract and neem (Azadirachia indica) oil could 
restrict growth of the anthracnose fungus Among the bio fungicides used against the fungus Colletotrichum sp. on chilli fruit (Jeyalakshmi, and Seetharaman, 1998; Korpraditskul et al., 1999 and Charigkapakorn, 2000).

Endophytic fungi live inside the plant without causing any overt negative effect on the host; rather they protect the host plant from pest and diseases (Saikkonen $\mathrm{K}$ et al., 2004). The ability of endophytic micro flora especially fungi provide protection against wide range of plant pathogens and insect herbivores (Clay, et al., 1985; Clay, 1988) and hence drawn the attention to study the endophytes for better health of crop plants and their Antifungal bioactivity (Kumar S, Kaushi, 2013; Clarke, et al., 2006; Kumar, Kaushik, et al., 2011; Li HY et al., 2010; Narisawa K, et al., 2002). However, selection and identification of effective antagonistic organisms is the first and foremost step in biological control (Campanile, 2007; Kamalakannan, 2004).

In view of the above mentioned facts, the present study was undertaken to characterize entophytic fungi isolated from rhizome of Acorus calamus Linn., and assess fungal antagonism against $C$. acutatum and $C$. gloeosporioides along with plant growth promoting traits in chilli crop at seedling stage.

\section{Materials and Methods}

\section{Fungal Pathogens}

Chilli fungal pathogens cultures of $C$. acutatum (MTCC2214) and $C$. gloeosporioides (MTCC 3439) were purchased from MTCC Chandigarh, India. The fungal culture were grown on PDA plates and incubated at $28^{\circ} \mathrm{c} 4-6$ days. Stock cultures were maintained on PDA slants.

\section{Isolation of Endophytic Fungi}

The endophytic fungus was isolated from the rhizome. Rhizomes were washed in running tap water and its scales were removed using a sterile blade. It was then washed with $70 \%$ ethanol for $1 \mathrm{~min}$, followed by $0.5 \%$ aqueous solution of sodium hypo chloride for 3 minute. It was again washed with $70 \%$ ethanol for 1-4 min and rinsed with sterile distilled water. It was aseptically cut with sterile blade and inner tissue was excised. The excised tissue pieces were inoculated to potato dextrose agar (PDA) containing $1 \mathrm{mM}$ Gentamicin (to avoid bacterial growth) inoculated for 6-25 days at $25 \pm 10 \mathrm{C}$. Pure cultures were then transferred to PDA plates free from antibiotics and cultivated for 20 days at 280C (Petrini, 1984).

\section{Screening of Endophytic Fungi for Antifungal Activity}

The isolated strains were screened for their antagonistic activity against $\mathrm{C}$. acutatum and C.gloeosporioides by dual culture method (Campanile, 2007). Mycelial growth (6 mm plugs with the mycelium) removed under aseptic conditions from 4 to 5 day-old pure culture of each isolate of endophytic fungi and pathogenic fungi was transferred to Petri dish $(9 \mathrm{~cm} 2)$ containing $20 \mathrm{ml}$ of PDA and was kept $4 \mathrm{~cm}$ apart from each other. The plates were incubated at $28^{\circ} \mathrm{C}$ for 8 days and the treatments were replicated in triplicates. The growth of the pathogen and the endophyte was observed constantly and radial growth was recorded by measuring the mean colony diameter on 8th day of inoculation. The percent of inhibition of the test phyto pathogenic fungi was calculated using the formula

$(\mathrm{R} 1-\mathrm{R} 2 / \mathrm{R} 1) \times 100$ 
Where R1 was the radial growth of pathogen without endophytic fungi, R2 represent the radial growth of pathogen inoculated with endophytic fungi (Ghildial \& Pandey, 2008).

\section{Identification of Endophytic Fungi}

The fungal cultures were identified based on colony morphology, conidial, shape-size and growth rate (Photita, 2005). Extraction of genomic DNA from the culture of strain was performed according to the extraction method described by Raeder and Broda P (1985).fungal identification was carried out by comparing the rRNA internal transcribed spacer (ITS) regions to sequences deposited in GenBank. ITS regions were amplified by PCR with primers forward (ITS4-5'TCCGTAGGTGAACC TGCGG-3') and reverse (ITS4-5'TCCTCCG CTTATTGAT ATGC-3') primers. A Peltier Thermal Cycler 200 (MJ Research) was employed, and the conditions for DNA amplification were as follows: an initial denaturation step of $5 \mathrm{~min}$ at $940 \mathrm{C}, 24$ cycles of $30 \mathrm{~s}$ at 94 OC (denaturation), $30 \mathrm{~s}$ at $550 \mathrm{C}$ (annealing), 30 $\mathrm{s}$ at $720 \mathrm{C}$ (elongation), and a final elongation step of $7 \mathrm{~min}$ at $720 \mathrm{C}$. The amp icons were purified with GFX columns. PCR products were sequenced using the same primers as those used for amplification. Each sequence was obtained in duplicate from each of two separate PCR amplifications Fungal identification was carried out by an analysis of similarity by means of the BLASTn tool suite from the BLAST software package (Astchul, et al., 1990) to compare its ITS1-5.8S- ITS2 region to sequences deposited in Gen Bank. To perform the phylogenetic analysis, ITS sequence of fungal strain was aligned with characterized sequences retrieved from GenBank by means of the tools available in the MEGA 4.0 software package (Tamura $\mathrm{K}$, et al., 2007). Tree reconstructions were obtained by the Neighbor-Joining method 1000 bootstrap replicates were performed to assess the statistical support for each branch in the tree.

\section{Production of Volatile Compounds by Endophytic Isolates}

The production of volatile substances by endophytic fungi was determined by growing the culture in sealed Petri plates. Inoculum in the form of $5 \mathrm{~mm}$ discs of endophytic fungi and test fungal pathogens were placed in the center of two separate bottom portions of Petri dish chamber of same size containing PDA, and one of the plates was placed in an inverted position over the other in such a manner they form a chamber. This set up was sealed with Para film and incubated at $280 \mathrm{C}$ for 8 days. Control was maintained without endophytic fungi in the bottom plate. Observation was recorded after one week and proportion of inhibition was calculated

\section{Qualitative Extracellular Enzyme Assay}

The isolates of endophytic fungi were tested for their ability to produce the hydrolytic enzymes i.e., amylase, protease and lipase (Hankin \& Anagnostakis, 1975; Kumaresan \& Suryanarayanan, 2002)

\section{Plant Growth Promoting Traits}

\section{Indole Acetic Acid (IAA)}

IAA was quantified by the method of Patten and Glick (2002). Fungal isolate was cultured in flasks containing $10 \mathrm{ml}$ of PDA broth supplemented with tryptophan (L-trp) $0.2 \mathrm{mM}$ and incubated at room temperature $\left(25\right.$ to $28^{\circ} \mathrm{C}$ ) for $72 \mathrm{~h}$. The cultures were then centrifuged for $15 \mathrm{~min}$ at $10000 \mathrm{rpm}$. Each $2 \mathrm{ml}$ of the supernatant was mixed with $2 \mathrm{ml}$ of Salkowski reagent $(150 \mathrm{ml}$ 
$\mathrm{H} 2 \mathrm{SO} 4,250 \mathrm{ml}$ distilled water, $7.5 \mathrm{ml}$ $\mathrm{FeCl}_{3} .6 \mathrm{H}_{2} \mathrm{O} 0.5 \mathrm{M}$ ) and incubated at room temperature for $30 \mathrm{~min}$. The presence of IAA was determined by the development of pink color and the IAA concentration was measured spectroscopically at $520 \mathrm{~nm}$ and quantified in an IAA standard curve.

\section{Production of Ammonia}

Fungal isolate was tested for the production of ammonia in peptone water. Freshly grown cultures were inoculated in $10 \mathrm{ml}$ peptone water in each tube and incubated for $48-72 \mathrm{~h}$ at $370 \mathrm{C}$ and $280 \mathrm{C}$. Nessler's reagent $(0.5 \mathrm{ml})$ was added in each tube. Development of brown to yellow color was a positive for ammonia production (Cappuccino and Sherman, 1992).

\section{Qualitative and Quantitative Analysis of Phosphate Solubilization}

The isolates were screened for phosphate solubilization as per methodology described by Gupta (1994). On modified Pikovskaya agar with insoluble tricalcium phosphate (TCA); a loop full of each culture was placed on the centre of agar plates and incubated at $30 \pm 0.10 \mathrm{C}$ for 5 days. The solubilization zone was determined by subtracting the diameter of fungal colony from the diameter of total zone.

Quantitative estimation of inorganic phosphate solubilisation was done as per methodology described by Nautiyal (2001) and Jackson (1973).Fungal isolate were grown in National Botanical Tricalcium phosphate (TCA). The flasks containing $50 \mathrm{ml}$ medium was inoculated with $500 \mu \mathrm{l}$ fungal culture in Tricalcium and incubated at $30 \pm 0.10 \mathrm{C}$ at $180 \mathrm{rpm}$ for 5 days in incubator shaker. Simultaneously, the un inoculated control was also kept under similar conditions. The cultures were harvested by centrifugation at 10,000 rpm for $10 \mathrm{~min}$. The phosphate in supernatant was estimated by vanado-molybdate-yellow color method. To a $0.5 \mathrm{ml}$ aliquot of the supernatant, $2.5 \mathrm{ml}$ Barton's reagent was added and volume was made to $50 \mathrm{ml}$ with deionized water. The absorbance of the resultant color was read after $10 \mathrm{~min}$ at430 $\mathrm{nm}$ in UV/Visible Spectrophotometer. The total soluble phosphorus was calculated from the regression equation of standard curve. The values of soluble phosphate liberated were expressed as $\mu \mathrm{g}$ ml-1 over control. The $\mathrm{pH}$ of culture supernatants were also measured using a $\mathrm{pH}$ Meter.

\section{Seed Treatment and Nursery Experiment}

Plastic pot trays containing 98 cavities filled with well sterilized coco peat was used to produce the chilli seedlings. Chilli seeds were treated with the 7 days old fungal culture broth $(1 \mathrm{ml})$ of the selected isolate 30 min and were shade-dried at 280C for $1 \mathrm{~h}$. The treated seeds (100) were sown in pots containing coco peat in a green house. Seed receiving only sterile distil water served as untreated controls. Seedlings were allowed to grow for 30 days $25+280 \mathrm{C}$ under natural light. Observations were recorded on germination percentage in the beginning, root length; shoot length and fresh weight of the seedlings every two weeks interval of sowing by removing 10 seedlings from each replication.

\section{Results and Discussion}

Isolation and Screening of Endophytic Fungi against Chilli Fungal Pathogens

A total 17 morphology distinct fungal colonies were isolated from rhizome of Acorus calamus. All 17 endophytic fungal isolates screened for fungal antagonism against Colletotrichum sp using dual culture 
method. Six endophytic fungal strains showed significant antagonism against test pathogenic fungi $C$. acutatum and $C$. gloeosporioides. Out of six fungal antagonistic isolates, one of the isolate P.citrinum (AVGE1) strain showed significantly higher antagonistic activity against the test pathogens.

\section{Identification of Endophytic Fungi}

Morphological nature of mycelium conidiophores and conidial characters were identified under light microscope. Based on the morphology of mycelium, nature, structure and arrangement of conidia and conidiophores AVGE 1 was tentatively identified as genus Pencillium sp (fig 1)

When amplified the ITS region of $r$ RNA of P.citrinum (AVGE 1) the primary ITS 1 and ITS 4 produced expected size of PCR product showing band at 553 bp. A Sequence similarity search showed that $18 \mathrm{~S} \mathrm{r}$ RNA sequence of AVGE1 showed 99\% similarity with their respective corresponding gene sequence of $P$. griseofulvum (EU497954.1), and P.citrinum (GU566273.1) in data base. A Phylogenetic analysis was Carried out with neighbor joining method revealed that it is closely related $P$. citrinum. The sequence was submitted in GEN BANK NCBI P.citrinum AVGE1 with accession number KM 389206 (Fig 2).

\section{Qualitative and Quantitative analysis of IAA, Ammonia and Phosphate solubilization}

P.citrinum (AVGE 1) showed positive response to phosphate solubilisation, IAA and Ammonia production. The isolate P.citrinum (AVGE 1) was tested for Quantitative production of IAA and Ammonia. P.citrinum AVGE 1 showed significantly high levels of IAA $(125 \mu \mathrm{g} / \mathrm{ml})$ and Ammonia $(16.08 \mu \mathrm{g} / \mathrm{ml})$. Another important trait in PGP is inorganic phosphate solubilization P.citrinum (AVGE 1) was capable of solubilizing inorganic phosphate with solubilisation index of 777 ppm (Table1)

Effect of Volatile Compounds on the Growth Pathogens

P. citrinum (AVGE1) strains showed visible inhibition due to production of volatile compounds against pathogenic fungi $C$. acutatum and $C$. gloeosporioides (data not shown)

\section{Hydrolytic Enzymes by P.citrinum (AVGE1)}

Plate assay for the production of hydrolytic enzymes indicated that $P$. citrinum (AVGE1) was positive to Amylase, lipase, protease production. Clear zone around the fungal colony indicating the positive amylase production and undigested gelatin precipitated with ammonium sulphate and the digested area around the colonies appeared clear and thus indicating the positive protease activity by the fungi. After incubation a clear zone around the colony indicated lipase positive activity by the fungi (Table 2). The result obtained revealed that P.citrinum (AVGE1) possessed excellent enzymatic activity.

\section{Effect of $P$. citrinum (AVGE1) on Growth of Chilli Seedlings}

P. citrinum (AVGE1) was characterized for its plant growth promotion ability on seedlings of chilli (Capsicum frutescence LCA 334). In vitro growth parameters root length, shoot length, leaf surface area determined for 100 seedlings at an interval of 2 weeks after sowing. Inoculation of pot 
trays containing chilli seeds with $P$.griseofulvum lead to a significant increase in growth parameters of chilli seedlings
(Table 2). P. citrinum (AVGE1) increased root length, shoot length, fresh weight and seedling vigor.

Table.1 Plant Growth Promotion Traits and Hydrolytic Enzyme Production of P.citrinum (AVGE1)

\begin{tabular}{|l|l|}
\hline PGPR traits & P.citinum (AVGE1) \\
\hline IAA & $125 \mu \mathrm{g} / \mathrm{ml}$ \\
\hline Ammonia & $16.08 \mu \mathrm{g} / \mathrm{ml}$ \\
\hline $\begin{array}{l}\text { Phosphate } \\
\text { solubilisation }\end{array}$ & $777 \mathrm{ppm}$ \\
\hline Amylase & Positive \\
\hline Protease & Positive \\
\hline Lipase & Positive \\
\hline
\end{tabular}

Table.2 Effect of P.citrinum (AVGE1) on Growth of Chilli Seedlings

\begin{tabular}{|l|l|l|l|l|l|}
\hline Time period & Name & $\begin{array}{l}\text { Root length } \\
(\mathrm{cm})\end{array}$ & $\begin{array}{l}\text { Shoot length } \\
(\mathrm{cm})\end{array}$ & $\begin{array}{l}\text { Fresh weight } \\
(\mathrm{gram})\end{array}$ & $\begin{array}{l}\text { Seedlings } \\
\text { vigor index\# }\end{array}$ \\
\hline $2^{\text {nd }}$ week & Control & $2.3 \pm 0.15$ & $3.64 \pm 0.15$ & $0.06 \pm 0.02$ & 594 \\
\cline { 2 - 6 } & $\begin{array}{l}\text { P.citrinum } \\
\text { (AVGE2) }\end{array}$ & $\begin{array}{l}6.17 \pm 0.02 \\
(168.26 \%)\end{array}$ & $\begin{array}{l}6.55 \pm 0.02 \\
(79.94 \%)\end{array}$ & $\begin{array}{l}2.58 \pm 0.02 \\
(4200 \%)\end{array}$ & 1272 \\
\hline $4^{\text {th }}$ week & Control & $4.86 \pm 0.15$ & $4.86 \pm 0.01$ & $0.09 \pm 0.01$ & 972 \\
\cline { 2 - 6 } & P.citrinum & $9.18 \pm 0.15$ & $9.55 \pm 0.04$ & $3.99 \pm 0.04$ & 1873 \\
& $($ AVGE2) & $(88.88 \%)$ & $(96.50 \%)$ & $(4333 \%)$ & \\
\hline \multirow{3}{*}{$6^{\text {th }}$ week } & Control & $6.55 \pm 0.15$ & $6.82 \pm 0.02$ & $0.16 \pm 0.01$ & 1337 \\
\cline { 2 - 6 } & P.citrinum & $15.18 \pm 0.01$ & $17.36 \pm 0.15$ & $4.17 \pm 0.15$ & 3254 \\
& (AVGE2) & $(131.75 \%)$ & $(154.54 \%)$ & $(2506 \%)$ & \\
\hline $8^{\text {th }}$ week & Control & $10.69 \pm 0.25$ & $10.93 \pm 0.02$ & $0.20 \pm 0.02$ & 2162 \\
\cline { 2 - 6 } & P.citrinum & $17.46 \pm 0.20$ & $20.88 \pm 0.17$ & $4.88 \pm 0.03$ & 3700 \\
& (AVGE2) & $(63.33 \%)$ & $(91.03 \%)$ & $(2340 \%)$ & \\
\hline
\end{tabular}

$*$ Values are mean of three replicates. $\pm S E$

\#Seedlings viour index $=$ seedling length $(\mathrm{cm}) \times$ germination percentage.

Vigor index calculated after every 2 weeks.

** Value in parenthesis is \% increase of growth compared to control.

Fig.1 Microscopic Observation of P.citrinum

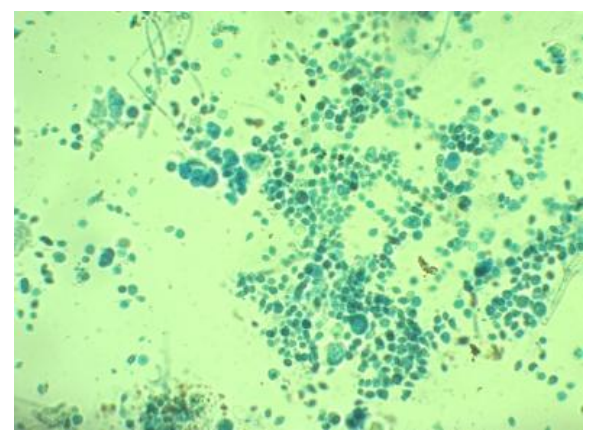


Fig.2 Phylogenetic Analysis of P.citrinum (AVGE1), Isolate based on $18 \mathrm{~S}$ rRNA base Sequence

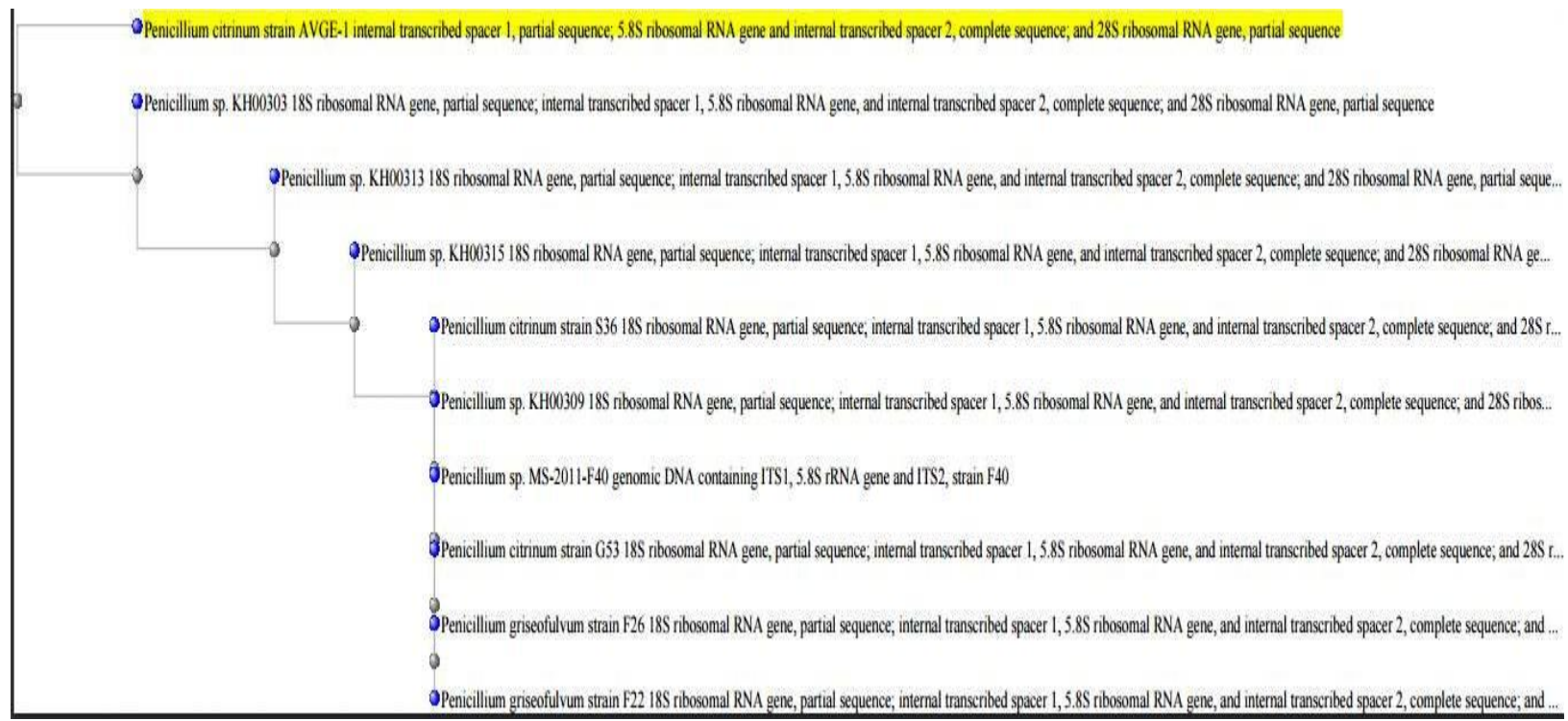

Fig.3 Green House Studies of Chilli Seedlings Treated with P.citrinum (AVGE1)

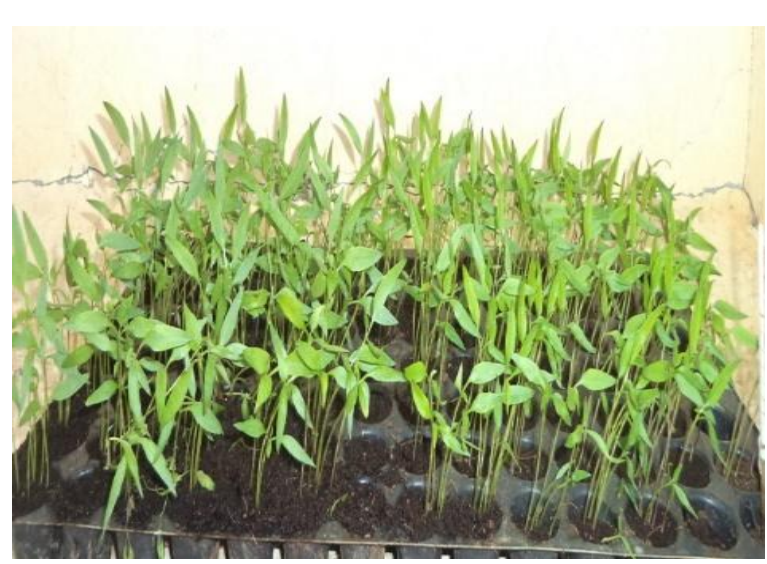

Control seedlings

The use of biological control methods to reduce disease incidence caused by phyto pathogens is continually being developed and is being used in a variety of crops (Soytong $\mathrm{K}$ et al., 2001). In the present study, P.citrinum (AVGE 1) showed inhibitory activity against both the test fungal pathogens. However, the antifungal activity demonstrated by endophytic fungi, P.citrinum was due to certain diffusible metabolites as revealed by dual culture

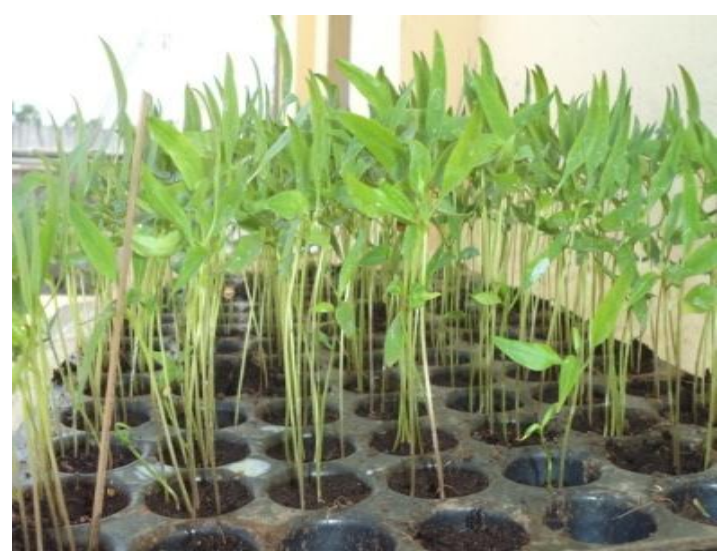

AVGE1 treated seedlings

method. The extracellular metabolites produced by endophytic fungi P.citrinum (AVGE1) are responsible to inhibit the pathogens. Fungal protease also plays a significant role in cell wall lysis that occurs during pathogen-host interactions (Haran $\mathrm{S}$ et al., 1996). P.citrinum (AVGE 1) produced higher quantities of IAA in culture broth and also induced their production within the treated chilli plants. The increase in IAA levels is one of the direct mechanisms by 
which bio control agents promote shoot and root growth and leaf area in chilli plants. The role of IAA in lateral and adventitious roots initiation and emergence, as well as in shoot development by influencing cell division, expansion and differentiation (Saikkonen, et al., 2011). They also colonize the plant roots, provide protection against certain soil borne fungal pathogens as well as stimulate growth and crop yield by hormonal stimulation through induction of host resistance by elicitation (Neito and Frankenberger, 1989). P.citrinum (AVGE1) has been reported to produce high levels of IAA and ammonia. These property were responsible for increased growth of chilli seedlings (table 2, fig3). Among different microbial groups, fungi have been reported to be more efficient phosphate solubilizer in comparison to bacteria. (Ahmad, et al., 2008) It is a well-established fact that improved phosphorous nutrition influences overall plant growth and root development (D.L. Jones \& P.R. Darrah, 1994). The plant growth promoting ability of fungi may be due to their capacity to produce higher amounts of growth promoting metabolites. P.citrinum (AVGE1) Inorganic phosphate solubilization was reported to be high (770 ppm) when compared to the earlier studies. The P.citrinum (AVGE1) tested positive for the production of ammonia, which is taken by plants as a source of nitrogen for their growth (Gour, et al., 1990) fungal endophytes thus facilitate their host plants to survive under stress condition by secreting favorable secondary metabolites

The results from this study also showed that the fungal endophyte P.citrinum (AVGE1) can produce a variety of volatile compounds (VOCs) and showed antifungal activity against Colletotrichum pathosystems. Many endophytic species reported to produce volatile antibiotics substance (Strobel, 2002; Schulz, 2005; Wang, et al., 2007) However, less than half of these compounds are of importance in bio control strategy as most of the volatiles are non-inhibitory in nature.

The present study has clearly demonstrated that P.citrinum (AVGE1) can be employed for basal application in pot trays to raise quality chilli seedlings to induce systemic resistance against Anthracnose disease caused by Colletotrichum species. This study therefore assumes significance in production of diseases free quality chilli transplants. Based on this study and other data a seed coating formulation, has been developed and its utility in enhance seed germination, seedling growth and vigor with resistance to seed borne fungal pathogens. Management and control of the anthracnose disease are still under extensive research (Yoon, et al., 2004). Among disease control management, the use of resistant cultivars is the cheapest, easiest, safest and most effective means of controlling the disease. This is not only to eliminate losses from the disease but also decrease the cost of chemical and mechanical control, as well as reduce contamination of the environment from the use of toxic chemicals.

The potentiality of P.citrinum (AVGE1) bio control agent under in vivo conditions from the point of view whether there is any varietal or location variations in harbouring and its expression against the tested pathogens and on the occurrence of diseases in nature in chilli fields where the endophyte commonly occurs need to be explored in future.

\section{Acknowledgement}

I am thankful to Acharya Nagarjuna University, Guntur, and A.P. for granting University Research Fellowship to do my research work.

\section{References}


Gour, A.C. 1990. Eds. phosphate solubilizing micro-organisms as biofertilizers. Omega scientific publishers. New Delhi, 16-72.

Astchul, S.F., Gish, W., Miller, W., Myers, E.V., Lipman, D. 1990. basic local alignment tool. J. Mol. Boils., 215: 403-410.

Bosland, P.W., Votava, E.J. 2003. Peppers: Vegetable and Spice Capsicums. CAB International, England, p.233.

Brick, J.M., Bostock, R.M., Silverstone, S.E. 2004. Rapid insitu assay for indole acetic acid production by bacteria immobilized on nitrocellulose membrane. Appl, Environ. Microbial., 57: 535-538.

Charigkapakorn, N. 2000. Control of Chilli Anthracnose by Different Biofungicides. Thailand. Available from http:// www.arcavrdc.org/pdf_files/029-

Charigkapakorn_18th.pdf (Accessed 24/06/2008).

Clay, K., Hardy, T.N., Hammond, A.M., Jr 1985. Fungal entophytes of grasses and their effects on an insect herbivore. Oecologia. 66: 1-5.

Clay, K. 1988. Fungal entophytes of grasses: defensive mutualism between plants and fungi. Ecol., 69: 10-16.

Campanile, G., Ruscelli, A., Luisi, N. 2007. Antagonistic activity of endophytic fungi towards Diplodiacorticola assessed by in vitro and in planta tests. Eur. J. Plant Pathol., 117: $237-$ 246.

Clarke, B.B., White, J.F. Jr, Hurley, R.H., Torres, M.S., Sun, S. 2006. Endophyte mediated suppression of dollar spot disease in fine fescues. Plant Dis., 90: 994-998.

Cappuccino, J.G., N. Sherman. 1992. Biochemical activities of microorganisms. In: Microbiology, A Laboratory Manual. The Benjamin /
Cummings Publishing Co.California, USA.

Jones, D.L., P.R. Darrah. 1994. Role of root derived organic acids in the mobilization of nutrients from the rhizosphere. Plant Soil, 166: 247-257.

Ahmad, F., Ahmad, I., Khan, M.S. 2008. Screening of free-living rhizospheric bacteria for their multiple plant growth-promoting activities. Microbiol. Res., 163: 173-181.

Gupta, R.S., S. Rekha, Aparna, R.C. Kuhad. 1994. A modified plate assay for screening phosphate solubilizing microorganisms. J. Gen. Appl. Microbiol., 40: 255-260.

Ghildial, A., Pandey, A. 2008. Isolation of cold tolerant antifungal strains of Trichoderma sp. from glacier sites of Indian Himalayan region. Res. J. Microbiol., 3(8): 559-564.

Hankin, L., Anagnostakis, S.L. 1975. The use of solid media for detection of enzyme production by fungi. Mycologia, 67: 597-607.

Haran, S., Schickler, H., Chet, I. 1996. Molecular mechanisms of lytic enzymes involved in the biocontrol activity of Trichoderma harzianum. Microbiol., 142: 2321-2331.

Hadden, J.F., Black, L.L. 1989. Anthracnose of Pepper Caused by Colletotrichum spp. Proceeding of the International Symposium on Integrated Management Practices: Tomato and Pepper Production in the Tropics. Asian Vegetable Research and Development Centre, Taiwan, p.189-199.

Idris, E.E.S., Igiesias, D., Talon,M., borriss, R. 2007. Tryptophan dependent production of indole -3-acetic acid (IAA) affects level of plant growth promotion by Bacillus amyloliquefaciens FZB42. Mol. plant - microbe interaction, 20: 619-626. 
Jackson, M.L. 1973. Estimation of phosphorus content. Soil chemical analysis, Printer Hall, New Delhi (India).

Jeyalakshmi, C., Seetharaman, K. 1998. Biological control of fruit rot and dieback of chilli with plant products and antagonistic microorganisms. Plant Dis. Res., 13: 46-48.

Deddad, J., Alyan, A., H., Proksch, P. 2010. Methods for isolation of marine derived endophytic fungi and their bioactive secondary products, Nat. Protoc.

Kamalakannan, A., Mohan, L., Harish, S., Radjacommare, R., Amutha, G,. Chiara, K., Karuppiah, R., Mareeswari, P., Rajinimala, Angayarkanni, T. 2004. Biocontrol agents induce disease resistance in Phyllanthusniruri Linn against camping-off disease caused by Rhizoctoniasolani. Phytopathol. Mediterr., 43:187-194.

Korpraditskul, V., Rattanakreetakul, C., Korpraditskul, R., Pasabutra, T. 1999. Development of Plant Active Substances from Sweet flag to Control Fruit Rot of Mango for Export. In: Proceeding of Kasetsart University Annual Conference. Kasetsart University, Bangkok, p.34.

Kumar, S., Kaushik, N. 2013. Endophytic fungi isolated from oilseed crop Jatropha curcas produces oil and exhibit antifungal activity. PLoS One, 8: 1-8.

Kumar, S., Kaushik, N., Edrada-Ebel, R.A., Ebel, R., Proksch, P. 2011. Isolation, characterization and bioactivity of endophytic fungi of Tylophora indica. World J. Microbiol. Biotechnol., 27: 571-577.

Kumaresan, V., Suryanarayanan, T.S. 2002. Endophyte assemblages in young, mature and senescent leaves of
Rhizophora apiculata: evidence for the role of endophytes in mangrove litter degradation. Fungal Divers, 9: 81-91.

Li, H.Y., Zhao, C.A., Liu, C.J., Xu, X.F. 2010. Endophytic fungi diversity of aquatic/riparian plants and their antifungal activity in vitro. $J$. Microbiol., 48: 1-6.

Liu, X.D., Yan, X. 2008. A novel raw starch digesting $\alpha$-amylase from a newly isolated Bacillus sp. YX-1: purification and characterization. Biores. Technol., 99: 4315- 20.

Lorck, H. 2004. Production of hydrocyanic acid by bacteria. Plant Physiol., 1: 142-146.

Maria, G.L., Sridhar, K.R., Raviraja, N.S. 2005. Antimicrobial and enzyme activity of mangrove endophytic fungi of southwest coast of India. $J$. Agricultural Technol., 1: 67-80.

Neito, K.F., W.T. Frankenberger. 1989. Biosynthesis of cytokinins produced by Azoto bacterchroococcum. Soil. Biochem., 21: 967-972.

Narisawa, K., Kawamata, H., Currah, R.S., Hashiba, T. 2002. Suppression of Verticillium wilt in eggplant by some fungal root endophyte. Eur. J. Plant Pathol., 108: 103-109.

Nautiyal, C.S., S. Mehta. 2001. An Efficient Method for Qualitative Screening of Phosphate-Solubilizing Bacteria. Microbiol., 43: 51-56.

Patten, C.L., Glick, B.R. 2002. Role of Pseudomonas putidaindole-acetic acid in development of the host plant root system. Appl. Environ. Microbiol., 68: 3795-3801.

Petrini, O. 1984. Endophytic fungi in British ericaceae: a preliminary study. Trans. Brit. Mycol. Soc., 83: 510-512.

Photita, W., Taylor, P.W.J., Ford, R., Hyde, K.D., Lumyong, S. 2005. Morphological and molecular 
characterization of Colletotrichum species from herbaceous plants in Thailand. Fungal Divers, 18: 117133.

Raeder, U., Broda, P. 1985. Rapid preparation of DNA from filamentous fungi. Lett. Appl. Microbiol., 1: 1720.

Strobel. 2002. Rainforest endophytes and bioactive products. Crit. Rev. Biotech., 22: 315-333.

Schulz, B., Boyle, C. 2005. The endophytic continuum. Mycol. Res., 109: 661686.

Soytong, K,. Kanokmedhakul, S., Kukongviriyapa, V., Isobe, M. 2001. Application of Chaetomium species (Ketomium) as a new broad spectrum biological fungicide for plant disease control:a review article. Fungal Divers, 7: 1-15.

Saikkonen, K., S.H. Faeth, M. Helander, 51. Sun, X., L.D. Guo and K.D. Hyde, 2011. Community T.J. Sullivan, 1998. A continuum of interactions with composition of endophytic fungi in Acer truncatum the host plants. Annual Review of Ecology and and their role in decomposition. Fungal
Divers. Systematic., 29: 319-343. 47: 85-95.

Saikkonen, K., Wali, P., Helander, M., Faeth, S.H. 2004. Evolution of endophyte-plant symbiosis. Trend Plant Sci., 9: 275-280.

Soytong, K., Kanokmedhakul, S., Kukongviriyapa, V., Isobe, M. 2001. Application of Chaetomium species (Ketomium) as a new broad spectrum biological fungicide for plant disease control: a review article. Fungal Divers, 7: 1-15.

Tamura, K., Dudliey, J., Nei, M., Kumar, S.M. 2007. molecular evolutionary genetics analysis (MEGA) software version 4.0 Mol. Boil. Evol., 24: 15961599.

Wang, F.W., Jiao, R.H., Cheng, A.B., Tan, S.H., Songy, C. 2007. Antimicrobial potentials of endophytic fungi residing in Quercus variabilis and brefeldin A obtained from Cladosporium sp. World J. Microbiol. Biotech., 23: 79-83.

Yoon, J.B., Yang, D.C., Lee, W.P., Ahn, S.Y., Park, H.G. 2004. Genetic resources resistant to anthracnose in the genus Capsicum. J. Korean Soc. Horticultural Sci., 45: 318-323.

\section{How to cite this article:}

Ganga Mani, P., and Amrutha V. Audipudi. 2016. Penicillium citrinum AVGE1 an Endophyte of Acorus calamus its Role in Bio Control and PGP in Chilli Seedlings. Int.J.Curr.Microbiol.App.Sci.5(5): 657-667. doi: http://dx.doi.org/10.20546/ijcmas.2016.505.066 